\section{Prenatal selection in XO mice}

SIR - Ashworth et al. ${ }^{1}$ attribute to me as a 'personal communication' the statement: "In contrast to humans, mice that are $\mathrm{XO}$ are viable with no prenatal lethality." The point I communicated to the authors was that if you compare the preimplantation and postnatal frequency of XOs borne by mice with two X chromosomes, there is no evidence of prenatal selection against XOs. However, there is now good evidence that there is considerable in utero selection against XOs borne by mice with a single $\mathrm{X}$ chromosome $\mathrm{e}^{2}$. Because in humans one is dealing with XOs borne by $\mathrm{XX}$ mothers, I believe our data provide the relevant comparison.

Why should there be this disparity between the fate of XOs borne by mothers with one as compared to two $\mathrm{X}$ chromosomes? I believe the answer lies in the poor quality of the embryos produced by mothers with a single $X$ chromosome, which can be attributed to a deficiency of X-linked products in the developing oocytes ${ }^{3}$. This poor embryo quality causes elevated losses during pregnancy, with all genotypes being affected; but I contend that there is preferential loss of the XO conceptuses because they are already developmentally compromised ${ }^{4}$.

\section{PAUL S. BURGOYNE}

MRC Mammalian Development Unit,

Wolfson House,

4 Stephenson Way,

London NW1 2HE, UK

1. Ashworth, A. et al. Nature 351, 406-408 (1991).

2. Hunt, P. A. Development 111, 1137-1141 (1991)

3. Burgoyne, P. S. \& Biggers, J. D. Dev/ Biol. 51, 109-117 (1976).

4. Burgoyne, P. S. et al. J. Reprod. Fert. 68, 387-393 (1983).

RASTAN ET AL. REPLY - The point Burgoyne makes was mentioned in our original manuscript, but deleted to comply with the word limit imposed by Nature.

Clinical Research Centre, SOHAILA RASTAN*

Watford Road, Harrow,

Middlesex HA1 3UJ, UK

*Other signatories: Alan Ashworth, Robin Loveli-Badge and Graham Kay.

\title{
Mucosal transmission of HIV
}

SIR - Mucosal transmission of the human immunodeficiency virus (HIV) by the vaginal mucosa in heterosexual, or rectal mucosa in homosexual subjects can be responsible for $70-80$ per cent of cervico-vaginal, oral and rectal epithelia identifying them by the CD1-specific monoclonal antibody (NA1/34) and their reaction with anti-HLA DR antibodies (see table). We found large numbers of

LANGERHANS CELLS IN EPITHELIAL TISSUES

\begin{tabular}{lcc} 
& \multicolumn{1}{c}{$\begin{array}{c}\text { Monoclonal antibodies } \\
\text { Tissues }\end{array}$} & HLA-DR* \\
& CD1(NA1/34) & $10 / 10$ \\
Oral epithelium & $10 / 10$ & $10 / 10$ \\
Vaginal epithelium & $10 / 10$ & $13 / 13$ \\
Cenvical epithelium & & $7 / 7$ \\
Ectocervical squamous epithelium & $13 / 13$ & $\dagger$ \\
Transformation zone & $6 / 7$ & $\dagger$ \\
Endocervical columnar epithelium & $9 / 13$ & $0 / 14$ \\
Rectal epithelium & $0 / 14$ &
\end{tabular}

Fresh frozen sections of human oral, vaginal, cervical and rectal tissue were stained by monoclonal antibodies using the Avidin-Biotin-peroxidase complex method described in ref. 6 . Control sections without the monoclonal antibodies were negative.

* HLA-DR from Becton Dickinson, and from RFDRI, The Royal Free Hospital, London.

† Most endocervical epithelial cells react with anti-HLA DR antibodies, so it is difficult to differentiate those from Langerhans cells.

AIDS. As Barbara Culliton points out ${ }^{1}$, heterosexual transmission of AIDS received a great deal of attention at the seventh international conference on AIDS. In particular, William Haseltine's view that AIDS should be recognized as a "lethal venereal disease" needs to be carefully considered. Langerhans cells and the related dendritic cells appear to be the most readily infectable cells by $\mathrm{HIV}^{2}$. Indeed, chronic genital or systemic infection with the simian immunodeficiency virus in rhesus monkeys results in significant localization of the virus in Langerhans cells and macrophages of the genital-tract epithelium ${ }^{3}$.

We investigated Langerhans cells in

Langerhans cells in the vaginal and ectocervical squamous epithelium, and a smaller number in the endocervical columnar epithelium, as well as in the transformation zone of the cervix which could represent the most vulnerable part of the female genital tract in HIV transmission (see table). Oral mucosa contains a comparable number of Langerhans cells to that found in vaginal epithelium but we did not find Langerhans cells in rectal epithelium. Langerhans and dendritic cells may account for HIV infection of the cervicovaginal epithelium, or after rectal trauma the dendritic cells present in the rectal lymphoid follicles may be infected.
The enhanced risk of HIV transmission via seminal fluid may be accounted for by the high concentration of virus particles $\left(10^{8}\right.$ per $\left.\mathrm{ml}\right)$ in seminal fluid which is much higher than that found in serum $^{4}$. In seems, therefore, that HIVinfected seminal fluid may be transmitted to Langerhans and dendritic cells in the vaginal and oral epithelia. However, there is no convincing evidence that HIV particles in seminal fluid ejaculated during oral sex gain entry through the oral mucosa. Furthermore, there is no real evidence that intimate kissing between seropositive and seronegative subjects may lead to oral transmission of HIV, though this might be accounted for by the low frequency of isolation and low concentration of HIV in saliva.

An alternative mechanism for HIV transmission should be considered and, indeed, antibody mediated enhancement enables HIV to bind CD4-negative cells ${ }^{5}$. We have recently identified $\mathrm{Fc}$ receptors for IgG (FcyRIII and FcyRII) in the endocervical and transformation zone epithelia (L. H. et al, in preparation) and in rectal epithelial cells ${ }^{6}$ but not in oral squamous epithelial cells of normal human subjects. We suggest that Fc $\gamma$ receptors enable HIV-antibody complexes in seminal fluid to bind to cervical or rectal epithelial cells. These cells could then become permissive to HIV infection, or the complex could move to the basal epithelial surface and infect the $\mathrm{CD}_{4}{ }^{+} \mathrm{T}$ cells, dendritic cells or macrophages in the connective tissue.

It is evident that at least two mechanisms are available for cervico-vaginal and rectal mucosal HIV transmission: direct HIV infection of Langerhans and dendritic cells or the binding of HIV-antibody complexes to Fc $\gamma$ receptors on endocervical and rectal epithelial cells which may infect these or the adjacent $\mathrm{CD} 4^{+}$ cells. The two modes of mucosal entry of HIV need to be investigated urgently, as they might be used in cervico-vaginal and rectal routes of immunization against HIV infection.

THOMAS LEHNER LUMA HUSSAIN JANE WILSON MiCHAEL CHAPMAN

Division of Immunology, and of Gynaecology and Obstetrics,

UMDS of Guy's and St Thomas' Hospitals,

London SE1 9RT, UK

1. Culliton, B. J. Nature 352, 15 (1991).

. Macatonia, S. E., Lau, R., Patterson, S., Pinching, A. J. \& Knight, S. C. Immunology 71, 38-45 (1991).

3. Miller, C. et al. 7th Int. AIDS Conf. (Abstr. W. A.1119) 2 , 121 (1991).

4. Borzy, M. S., Connell, R. S. \& Kiessling, A. A. AIDS 1 419-424 (1988)

. Takeda, A., Tuazon, C. U. \& Ennis, F. A. Science 242 580-583 (1988)

6. Hussain, L. A. et al. AlDS 5, 1089-1094 (1991). 